\title{
The utilization of discarded oil from potato chip factories in toilet soap making
}

\author{
By Adel Y. Girgis \\ Oils and Fats Res. Dept., Food Tech. Res. Institute, Agriculture Res. Center, 9
El Gamaa St., Post N 12619, Giza, Egypt
}

RESUMEN

Diagrama ternario de sistemas de extracción proteínas/disolvente: Proteínas de sésamo, soja y altramuz.

El aceite de palma que se desecha de las fábricas de patatas chips se utilizó para producir jabón de tocador. Dicho aceite se purificó mediante lavado con una salmuera y blanqueado con $\mathrm{H}_{2} \mathrm{O}_{2}$. El aceite ya purificado (P.B.D.P.O.) se mezcló en diferentes proporciones con dos materiales normalmente utilizados en la fabricación de jabón de tocador, sebo no comestible (I.T) y aceite de semilla de palma (P.K.O.), obteniéndose los jabones correspondientes. Los datos demostraron que la utilización de P.B.D.P.O. hasta una proporción del $30 \%$ como sustituto del I.T. producía un jabón de tocador fino a juzgar por su consistencia, superficie suave, formación de espuma en las manos y erosión media en el lavado a mano. Las muestras de los jabones que contenían más del $30 \%$ de P.B.D.P.O. ya daban calidades deficientes. Después de un almacenamiento del jabón durante 6 meses a temperatura ambiente se produjo una mejora significativa variable de las propiedades físicas de los mismos. Según los resultados encontrados, se puede recomendar la utilización del aceite de desecho de las fabricas de patatas chips, previa purificación y blanqueo, en sustitución de hasta un $30 \%$ de sebo no comestible para la producción de jabón de tocador.

PALABRAS-CLAVE: Aceite de palma usado - Aceite de semilla de palma - Fabricación jabón de tocador -Sebo no comestible.

\section{SUMMARY}

The utilization of discarded oil from potato chip factories in toilet soap making.

Palm oil that was discarded as waste from chip factories after the frying of potatoes was used for the production of toilet soap. The discarded oil was purified with a brine solution and bleached with $\mathrm{H}_{2} \mathrm{O}_{2}$. Purified bleached discarded palm oil (P.B.D.P.O.) was mixed with two materials commonly used in toilet soap manufacturing, i.e., inedible tallow (I.T.) and palm kernel oil (P.K.O.) at different ratios for the preparation of toilet soap. The data revealed that using P.B.D.P.O. up to $30 \%$ as a substitute for I.T. produced fine toilet soaps from the view point of: hard consistency, soft surface, good hand lather preference and medium erosion from hand washing. The soap samples containing more than $30 \%$ P.B.D.P.O. as a substitute for I. T. gave bad quality. After the storage of soap samples for 6 months at room temperature, significant improvements in the physical properties of the soap samples at different ratios were found. It could be recommended that discarded palm oil from chip frying factories can be used after purification and bleaching in place of inedible tallow up to $30 \%$ to produce a fine toilet soap.

KEY-WORDS: Discarded palm oil - Inedible tallow - Palm kernel oil - Toilet soap manufacture.

\section{INTRODUCTION}

Soap is an essential cleansing agent in our daily life. Soap (sodium salt of fatty acid) is the oldest known surfactant and has been used since the Egyptian era (Kaoru 1998). Ainie et al. (1996) reported that soap is a mixture of sodium salts of the following fatty acids: stearic, palmitic, myristic, lauric and oleic acids and that these acids contribute to the lathering and washing properties of soap. Traditionally, the raw materials used for toilet soap making have always been tallow and coconut oil (Ainie and Hamirin 1994). Edmund (1994) tallied that palm oil and palm kernel oil can be used as alternatives to tallow and coconut oil, respectively in toilet soap. Also, the same author found that the fatty acid compositions of palm oil and palm kernel oil are similar to tallow and coconut oil, respectively. Sonntay (1981) mentioned that palm kernel oil or coconut oil is required in toilet soap to produce a soft, gentle soap. Generally, the ratio of palm oil to palm kernel oil is either $85-15 \%$ or $80-20 \%$, respectively (Jaya et al., 2000). In Egypt, the manufacturing of toilet soap is being carried out from a blend of $85 \%$ tallow or palm stearin or a mixture of them with $15 \%$ palm kernel oil (The Egyptian Industry Ministry, 2002).

A hydrogen peroxide solution is used to improve the colour of the palm oil used in the manufacturing of soap (Woollatt 1985). According to Clark and Serbia (1991), and Tyagi and Vasishtha (1996), free fatty acid, viscosity, peroxide value, odour, taste, colour, iodine value, refractive index, smoke point and saponification values are used to determine the quality of frying fat. These tests are used as indicators to change (discard) frying oils in chip factories. In Egypt, the discarded frying oils from chip factories are not utilized and these waste oils cause many environment problems.

Therefore, the main aim of this research was to utilize the discarded oils from chip factories as an alternative source for inedible tallow of up to $30 \%$ in toilet soap manufacturing and to reduce the production cost of toilet soap as well as to lessen environmental pollution. 


\section{MATERIALS AND METHODS}

\subsection{Materials}

- Inedible tallow [I.T.] and palm kernel oil [P.K.O.] were obtained from Cairo Oils and Soap Company, Cairo, Egypt.

- Discarded and fried palm oil [after the frying of potatoes] was taken from Golden Frites Company, Cairo, Egypt.

- Sodium hydroxide and hydrogen peroxide solutions were brought from EL-Gomhoria Company for Pharmaceutical, Cairo, Egypt.

- Sodium chloride was supplied from EL-Nasr Salinas Company, Alexandria Governorate, Egypt.

\subsection{Methods}

\subsubsection{Purification of discarded palm oil}

Fried and discarded palm oil was heated to $90 \pm$ $5^{\circ} \mathrm{C}$ and washed with a hot brine solution $[5 \% \mathrm{NaCl}$, $\mathrm{w} / \mathrm{v}]$. The ratio of discarded oil and brine solution was $10: 1(\mathrm{v} / \mathrm{v})$. The hot mixture [discarded oil and brine solution] was stirred using a stirrer at a speed of 60 rpm for $60 \mathrm{~min}$. After that, the mixture was left to rest for $8 \mathrm{hrs}$ in order to separate the mixture into two phases. The bottom phase [brine solution +impurities] was separated by siphoning. Sodium sulphite anhydrous was added to catch the traces of moisture from discarded palm oil, which was then filtered through filter paper (Whatman no. 1). The colour [using Lovibond tintometer, model E] and impurities of discarded palm oil before and after purification were determined according to the methods described in the A.O.C.S. (1997); while the odour was evaluated according to the method reported by Shyam (1991).

\subsubsection{Bleaching of purified discarded palm oil}

Purified discarded palm oil was heated to $70 \pm 5^{\circ} \mathrm{C}$ and bleached with a $2 \% \mathrm{H}_{2} \mathrm{O}_{2}$ solution $(\mathrm{v} / \mathrm{v})$. The sample was stirred using a stirrer at a speed of 80 rpm for 30 min while maintaining a temperature of 70 $\pm 5^{\circ} \mathrm{C}$. The discarded palm oil was filtered through filter paper [Whatman no. 1] and the colour was measured.

\subsubsection{Determination of some physical and chemical properties of the fatty materials}

Moisture and volatile matter (\%), acidity (\%) (as oleic and lauric acids for inedible tallow [I.T.] and palm kernel oil [P.K.O.] along with palmitic acid for both palm oil [P.O.] and purified bleached discarded palm oil [P.B.D.P.O.], respectively), peroxide value
[Meq. $\mathrm{O}_{2} / 1 \mathrm{~kg}$ oil], saponification value, iodine number [Hanus], titer number $\left({ }^{\circ} \mathrm{C}\right)$, unsaponifiable matter (\%), smoke point $\left({ }^{\circ} \mathbf{C}\right)$ and impurities (\%) in I.T., P.K.O., P.O. and P.B.D.P.O. were determined according to the methods found in the A.O.C.S. (1997). In addition the refractive index (at 30 and $60^{\circ} \mathrm{C}$ ) was measured using Refractometer [N1 RL 3 - Poland] following the method described in the A.O.C.S. (1997). The colour was measured in the aforementioned fatty materials using Lovibond tintometer, model E, using 5.25 inch cell, according to the method found in the A.O.C.S. (1993). I.N.S. factor was calculated according to the method reported by Iftikar, (1981). Whereas the viscosity (absolute values in centistokes at 30 and $60^{\circ} \mathrm{C}$ ) was determined using Brookfiled digital viscometer, model PVDV-I+C/P, Cone/Spindle 40, speed sets 60 (R.P.M.) at $30^{\circ}$ and $60^{\circ} \mathrm{C}$, connected with water bath Brookfield TC 500, according to the method outlined by Leszkiewicz, and Kasperek, (1988).

\subsubsection{Methylation of fatty materials}

The methyl esters of I.T., P.K.O., P.O. and P.B.D.P.O. were prepared [using benzene: methanol: concentrated sulphuric acid (10:86:4)] and methylation was carried out by heating at $70^{\circ} \mathrm{C}$ for 24 hrs according to the method reported by Ludy et al. (1968).

\subsubsection{Identification and determination of fatty acid methyl esters}

The fatty acid methyl esters of I.T., P.K.O., P.O. and P.B.D.P.O. were separated and quantitatively determined using Gas-liquid chromatograph/Pye Unicam PRO-GC as the method reported by Zygadlo et al. (1994).

\subsubsection{Making of toilet soap samples}

One $\mathrm{kg}$ of various fatty blends, which contained I.T., P.K.O., P.O. and P.B.D.P.O. at different ratios (see Table I), was separately melted on a hot plate $\left(95 \pm 5^{\circ} \mathbf{C}\right)$ and saponified with sodium hydroxide $\left(95 \pm 5^{\circ} \mathrm{C}\right)$. The amounts of total sodium hydroxide used to complete the saponification of fatty blends were listed in the same table with $3.0 \%$ excess of sodium hydroxide. The concentration of sodium hydroxide solution used to individually saponify the aforementioned fatty blends was $37^{\circ}$ Bè (ranged from 8.1 to $8.5 \mathrm{~mol} /$ litre). The heated sodium hydroxide solution $\left(95 \pm 5^{\circ} \mathrm{C}\right)$ was separately added gradually to the heated fatty blends until complete saponification had taken place. Next, $10 \%$ hot water $(\mathrm{v} / \mathrm{v})$ at $95 \pm 5^{\circ} \mathrm{C}$ was added to homogenized soap paste to remove the excess amount of sodium hydroxide. After that, $10 \%$ heated brine solution $(\mathrm{v} / \mathrm{v})$ at $95 \pm 5^{\circ} \mathrm{C}$ (the concentration of 
Table I

Composition (w/w \%) and quantities of soap samples made from different fatty materials

\begin{tabular}{lcccccc}
\hline & \multicolumn{5}{c}{ Soap blend number } \\
$\begin{array}{l}\text { Ingredients and quantities of soap } \\
\text { samples }\end{array}$ & $\mathbf{7}$ & $\mathbf{2}$ & $\mathbf{3}$ & $\mathbf{4}$ & $\mathbf{5}$ & $\mathbf{6}$ \\
\cline { 2 - 6 } & 85 & - & 75 & 65 & 55 & 45 \\
\hline Inedible tallow (I.T.) (\%) & 15 & 15 & 15 & 15 & 15 & 15 \\
Palm kernel oil (P.K.O) (\%) & - & 85 & - & - & - & - \\
Palm oil (P.O.) (\%) & - & - & 10 & 20 & 30 & 40 \\
$\begin{array}{l}\text { Purified bleached discarded palm oil } \\
\text { (P.B.D.P.O) (\%) }\end{array}$ & 17.4 & 17.8 & 17.5 & 17.6 & 17.7 & 17.8 \\
Amount of sodium hydroxide (\%) & & & & & 1300 & 1315 \\
Contents of the resultant soaps (g) & 1280 & 1340 & 1285 & 1295 & 1300 \\
\end{tabular}

brine solution was $7-8 \% \mathrm{NaCl}$ ) was slowly added over the surface of the soap paste during its boiling to separate the glycerol water in the bottom, simultaneously, the saponified mass was floated on the surface. The glycerol water was removed by siphoning. Therewith, the soap paste was washed again with $5-10 \%$ hot water $(\mathrm{v} / \mathrm{v})$ at $95 \pm 5^{\circ} \mathrm{C}$ to reduce the excess amounts of sodium hydroxide and sodium chloride with any impurities found in the soap paste. The homogenized soap paste was tested during and after the complete saponification process by using the knife test, the fingers method and the total electrolyte content. After that, the soap paste was poured onto a wooden frame and left to harden at room temperature. The block of hardened soap was cut into small bars (about $150 \mathrm{~g}$ ) then stored for 6 months on a shelf at room temperature. Quantities of the produced soap samples were found in Table I. Soap sample no. 1 was the control soap. The resulting soap samples were analysed for their chemical properties at zero time and at different periods during the storage time (6 months), while the physical characteristics were determined only at zero time and after the ending of storage period (6 months).

\subsubsection{Determination of some chemical properties of the resultant soap samples}

Moisture content (\%), total fatty acids (\%), free alkali $(\mathrm{NaOH} \%)$, salt $(\mathrm{NaCl} \%)$, total electrolyte $(\%)$, free oil (\%), unsaponifiable matter (\%) and unsaponified matter (\%) in the derived soap samples were determined according to the methods described by The Egyptian Standard Specifications (1992) and the A.O.C.S. (1997).

\subsubsection{Determination of some physical properties of the resultant soap samples}

Consistency, hand lather preference, erosion from hand washing and titer number $\left({ }^{\circ} \mathrm{C}\right)$ of the obtained soap samples were determined according to the methods reported by Martin (1951), Ginn et al., (1968) and Shyam (1991).

\subsubsection{Statistical analysis}

The statistical analysis was performed according to the program found in SAS (1996).

\section{RESULTS AND DISCUSSION}

\subsection{Impact of washing with brine solution on the colour and impurities of discarded palm oil}

The Data in Table II show the effect of washing with brine solution $(5 \% \mathrm{NaCl}, \mathrm{w} / \mathrm{v})$ on the colour and impurities of discarded palm oil (D.P.O.). The ratio of discarded oil and brine solution was 10:1 (v/v). From these results, washing with brine solution induced some improvements in the colour and impurity levels (the total colour of D.P.O. reduced at a ratio of $8.0 \%$ and the impurity level decreased at a ratio of $33.3 \%$ after washing). The improvements may stem from the mutual solubility of the impurities in the brine solution. Therefore, the impurities were isolated in the bottom. These results are in harmony with those reported by Donald and Halloran (1991) who reported that simple wash water could be very 
Table II

Effect of washing with brine solution on some characteristics of discarded palm oil

\begin{tabular}{|c|c|c|c|c|c|c|c|c|}
\hline \multirow[b]{2}{*}{$\begin{array}{l}\text { Discarded } \\
\text { palm oil }\end{array}$} & \multicolumn{3}{|c|}{ Lovibond colour } & \multirow[b]{2}{*}{ Total colour } & \multirow{2}{*}{$\begin{array}{l}\text { Colour } \\
\text { reduction } \\
(\%)\end{array}$} & \multirow{2}{*}{$\begin{array}{c}\text { Impurities } \\
(\%)\end{array}$} & \multirow{2}{*}{$\begin{array}{c}\text { Reduction rate } \\
\text { of impurities } \\
(\%)\end{array}$} & \multirow[b]{2}{*}{ Odour } \\
\hline & Yellow & Red & Blue & & & & & \\
\hline $\begin{array}{l}\text { Before washing } \\
\text { step }\end{array}$ & 35.0 & 13.0 & 1.1 & 176 & - & 1.2 & - & $\begin{array}{l}\text { Like to potato } \\
\text { frying }\end{array}$ \\
\hline $\begin{array}{l}\text { After washing } \\
\text { step }\end{array}$ & 35.0 & 11.7 & 1.0 & 162 & 8.0 & 0.7 & 33.3 & $\begin{array}{l}\text { Slight odour to } \\
\text { potato frying }\end{array}$ \\
\hline
\end{tabular}

effective in improving the raw colour and impurity level of good tallow.

\subsection{Effect of bleaching with $\mathrm{H}_{2} \mathrm{O}_{2}$ on the colour of purified discarded palm oil (P.D.P.O.)}

The quality of fats and oils can often be improved through bleaching (Hilda, 1993). From data tabulated in Table III, it could be noted that the addition of $\mathrm{H}_{2} \mathrm{O}_{2}$ $(2 \% \mathrm{v} / \mathrm{v})$ caused a decrease in the total colour of P.D.P.O. from 162 before bleaching to 101 after bleaching, with a reduction ratio of $36.7 \%$. This improvement may be due to the action of $\mathrm{H}_{2} \mathrm{O}_{2}$ on some pigments (release free oxygen). This datum is in line with the findings of Woollatt (1985) who stated that a hydrogen peroxide solution is sometimes used as a bleaching agent.

\subsection{Fatty acid composition of the fatty materials}

Fatty acids are the main constituents of the fats and oils that affect soap making and its properties [lftikar 1981 and, Ogoshi and Miyawaki 1985]. The fatty acid compositions of I.T., P.K.O., P.O. and P.B.D.P.O. were tabulated in Table IV. From these data, it is clear that the fatty acid compositions of I.T., P.K.O. and P.O. were in line with those reported by many investigators [Chong 1994, Salmiah 1994 and Karimah et al., 2001]. The results showed that significant differences in the fatty acid compositions in either P.O. or P.B.D.P.O. were found. These variations are closely associated with the frying process. Also, data indicated that myristic, palmitic and stearic acids in P.O. increased from 1.8, 43.9 and $5.2 \%$ before frying to $3.8,48.8$ and $8.9 \%$ after frying when or while the frying produced increases in these acids at ratios of $+111.1,+11.2$ and $+71.1 \%$, respectively. On the contrary, palmitoleic, oleic and linoleic acids in P. O. reduced from 0.8, 36.8 and $10.4 \%$ before frying to $0.6,35.2$ and $2.3 \%$ after frying when or while the frying produced or caused reductions in these acids at ratios of $-25.0,-4.3$ and $-77.9 \%$, respectively.

These findings are similar to those found by Tyagi and Vasishtha (1996) who reported that during frying, a progressive decrease in unsaturation was observed in the oil by the determination of the iodine number. This decrease in unsatuaration may be due to the destruction of double bonds by oxidation, scission and polymerization.

\subsection{Physical and chemical characteristics of the fatty materials}

Some physical and chemical properties of the fatty materials used in this study are found in Table V.

Table III

Effect of bleaching with $\mathrm{H} 2 \mathrm{O} 2$ on the colour of purified discarded palm oil

\begin{tabular}{|c|c|c|c|c|c|c|c|c|}
\hline \multicolumn{4}{|c|}{ Before bleaching } & \multicolumn{5}{|c|}{ After bleaching } \\
\hline \multicolumn{3}{|c|}{ Lovibond colour } & \multirow{3}{*}{ Total colour } & \multicolumn{3}{|c|}{ Lovibond colour } & \multirow{3}{*}{$\begin{array}{l}\text { Total } \\
\text { colour }\end{array}$} & \multirow{3}{*}{$\begin{array}{l}\text { Colour } \\
\text { reduction } \\
(\%)\end{array}$} \\
\hline Yelow & Red & Blue & & Yellow & Red & Blue & & \\
\hline & & & & & & & & \\
\hline 35.0 & 11.7 & 1.0 & 162 & 35.0 & 6.2 & 0.4 & 101 & 36.7 \\
\hline
\end{tabular}


Table IV

Fatty acids composition (\%) of the fatty materials

\begin{tabular}{cccccc} 
Fatty acid & $\begin{array}{c}\text { Tallow } \\
\text { (I.T.) }\end{array}$ & $\begin{array}{c}\text { Palm kernel } \\
\text { oil (P.K.O.) }\end{array}$ & $\begin{array}{c}\text { Palm oil } \\
\text { (P.O.) }\end{array}$ & $\begin{array}{c}\text { Purified bleached } \\
\text { discarded palm oil } \\
\text { (P. B. D. P. O.) }\end{array}$ & $\begin{array}{c}\text { Change ratio between } \\
\text { P.O. / P.B.D.P.O. (\%) }\end{array}$ \\
\hline $\mathrm{C}_{12: 0}$ & - & 48.8 & - & - & \\
$\mathrm{C}_{14: 0}$ & 5.7 & 17.7 & 1.8 & 3.8 & +111.1 \\
$\mathrm{C}_{16: 0}$ & 26.0 & 9.9 & 43.9 & 48.8 & +11.2 \\
$\mathrm{C}_{16: 1}$ & 1.9 & - & 0.8 & 0.6 & -25.0 \\
$\mathrm{C}_{18: 0}$ & 18.2 & 4.0 & 5.2 & 8.9 & +71.1 \\
$\mathrm{C}_{18: 1}$ & 44.1 & 15.6 & 36.8 & 35.2 & -4.3 \\
$\mathrm{C}_{18: 2}$ & 3.3 & 3.1 & 10.4 & 2.3 & -77.9 \\
$\mathrm{C}_{18: 3}$ & Trace & - & 0.5 & Trace & - \\
Unkown & Trace & - & Trace & Trace & - \\
Total saturated fatty acids \% & 49.9 & 80.4 & 50.9 & 61.5 & +20.8 \\
Total unsaturated fatty acids \% & 49.3 & 18.7 & 48.5 & 38.1 & -21.4 \\
\hline
\end{tabular}

Where: Trace means less than $0.5 \%$.

From these data, it could be determined that the characteristics of I. T. were almost the same as those found by Woollatt (1985) and Shyam (1991). Also, the findings showed that the physical and chemical characteristics of P.K.O. and P.O. were in the range reported by Chong (1994). On the other hand, significant increases were found between P. O. and P.B.D.P.O. for the levels of acidity, P.V., S.V., I.N.S. factor, T.N., unsaponifiable matter, R.I. and viscosity.

On the contrary, the levels of I.N. and smoke point in P.B.D.P.O. recorded significant decreases compared with those of P.O. beside the fact that it is characterized by the darkest colour. These results are similar to those cited by many researchers [Perkins and Van Akkeren (1965), Wishner and Keeney (1965), El-Sharkawy et al. (1979), Izaki et al. (1984) and Tyagi and Vasishtha (1996) who found that these increments may be attributed to the formation of high molecular weight compounds during frying.

\subsection{Influence of purified bleaching discarded palm oil at different ratios on some chemical properties of toilet soap samples}

The characteristics of neat toilet soap samples are shown in Table VI. Chemical properties of soap sample no. 6 were not determined because its brittle phenomenon (breakable). This result is closely associated with the high content of P.B.D.P.O. Subsequently, this soap is not suitable for use. The moisture contents of soap sample no.s 1 and 3 were nearly the same. The data on moisture content of soap sample no.s. 1, 3, 4 and 5 were significantly lower than that found in soap no. 2. These differences may be attributed to soap sample no. 2 which had a high content of palm oil (85\%) compared with other soap samples (ranged from 10 to $30 \%$ ). In this respect, Ainie and Hamirine (1994) stated that the moisture content of neat toilet soap ranged from 20 to $35 \%$. The total fatty acids of soap samples no.s 1 , 3,4 and 5 were $71.8,71.5,71.1$ and $70.4 \%$, respectively which were significantly higher than that of soap sample no.2 (68.4\%). These variations can be due to the moisture content of soap sample no. 2, which was higher than that of the other soap samples. According to Ogoshi and Miyawakli (1985) and Hui (1996), the total fatty matter in neat toilet soap was in the range of $65-70 \%$.

The contents of free alkali, salt and total electrolyte in all soap samples (from 1 to 5 ) were in the range reported by The Egyptian Standard Specification (1992) for toilet soap and Ainie et al. (1996) for European soap [Which reported that both the contents of free alkali (as $\mathrm{NaOH}$ ) and salt (as $\mathrm{NaCl}$ ) should be less than $0.1 \%$ and $1.0 \%$, respectively], except the free alkali of soap sample no.2 which was significantly higher $(0.14 \%)$. This increase is due to the moisture content which was higher in soap sample no.2 compared with the other 

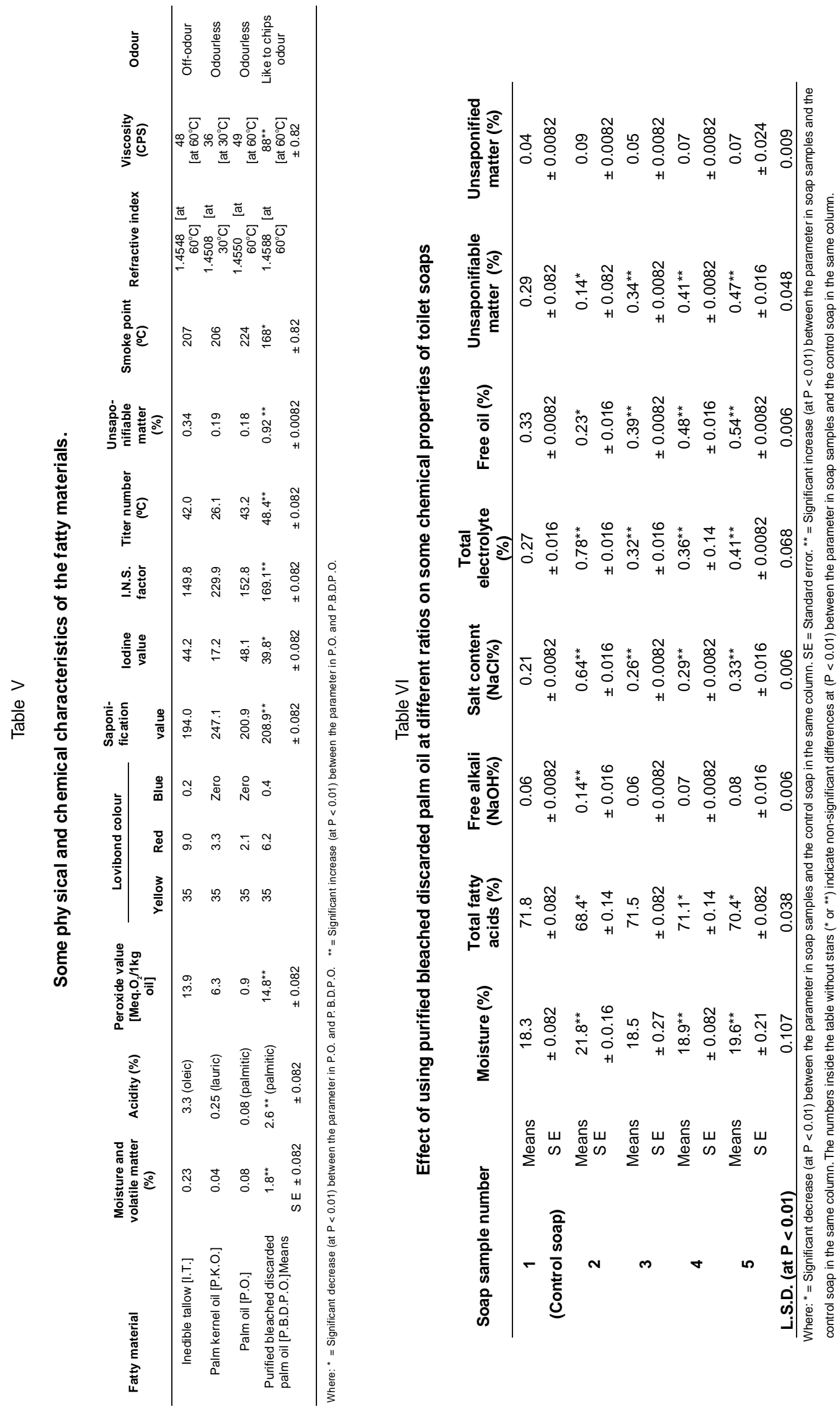


\section{Table VII \\ Influence addition of purified bleached discarded palm oil at different ratios on some physical properties of toilet soaps}

\begin{tabular}{|c|c|c|c|c|c|}
\hline \multirow[b]{2}{*}{ Parameter } & \multicolumn{5}{|c|}{ Soap sample number } \\
\hline & $\begin{array}{c}1 \\
\text { (Control } \\
\text { soap) }\end{array}$ & 2 & 3 & 4 & 5 \\
\hline $\begin{array}{c}\text { Consistency } \\
\text { Hand lather preference }\end{array}$ & $\begin{array}{c}\text { Hard } \\
\text { Very good }\end{array}$ & $\begin{array}{c}\text { Hard } \\
\text { Medium }\end{array}$ & $\begin{array}{c}\text { Hard } \\
\text { Very good }\end{array}$ & $\begin{array}{c}\text { Hard } \\
\text { Very good }\end{array}$ & $\begin{array}{l}\text { Hard } \\
\text { Good }\end{array}$ \\
\hline $\begin{array}{l}\text { Erosion from hand } \\
\text { washing }\end{array}$ & Low & Medium & Low & $\begin{array}{l}\text { Among low } \\
\text { to medium }\end{array}$ & Medium \\
\hline Titer number $\left[{ }^{\circ} \mathrm{C}\right]$ & 39.6 & 41.5 & 40.0 & 40.7 & 41.1 \\
\hline
\end{tabular}

soap samples. Highly significant differences in the content of free oil were found in all the soap samples. These differences might stem from the soap samples nos. 3,4 and 5, which were characterized by high contents of unsaponifiable matter. On other hand, the amount of unsaponified matter of all soap samples was less than $0.1 \%$. This means that the saponification process was complete. The Egyptian Standard Specifications (1992) for toilet soap mentions that the level of unsaponified matter should be less than $0.3 \%$.

From the above results, it is clear that some chemical properties of soap samples nos. 3, 4 and 5 are somewhat close to the control soap (soap no.1). Therefore, it can be concluded that soap samples nos. 3, 4 and 5, which contain up to $30 \%$ of P.B.D.P.O., were suitable for use.

\subsection{Impact of addition of purified bleached discarded palm oil at different ratios on some physical properties of toilet soap}

The lathering phenomenon is one of the most important attributes of bar soap perceived by the consumer [Shyam 1991]. Data in Table VII show the effect of using P.B.D.P.O. as a substitute for I.T. at different ratios on texture, hand lather preference, erosion from hand washing and titer number of soap samples. From these findings, it is clear that soap sample no. 6 was a low (bad) quality (easily broken). This datum may be due to the fact that soap sample no. 6 contains a high level of P.B.D.P.O. (40\%). The oil frying process induces some changes in the ratios of saturated and unsaturated fatty acids [Firestone et al., 1990]. Therefore, this ratio affected the consistency of soap no. 6 . On the other hand, the structures of other soap samples were the same (hard structure).

Moderate differences were found in both hand lather preference and erosion from hand washing of all soap samples (nos. 2, 3, 4 and 5) when compared with the control soap (no. 1). These differences may be attributed to the variations in the ratio of saturated to unsaturated fatty acids. In this respect, Jaya, et al.
(2000) demonstrated that the ratios of saturated and unsaturated, and the levels of long and short chains of fatty acids affect the quality of soap (foam ability, hardness and solubility in the finished soap). Data in Table VII show moderate variations in titer numbers of all soap samples (nos. 2, 3, 4 and 5) compared with the control soap (no.1). These changes can be related to the various levels of P.B.D.P.O. used in these soaps (T.N. of P.B.D.P.O. was $48.4^{\circ} \mathrm{C}$ ). On the other hand, the T.N. of all soap samples (from no. 1 to no. 5) are in the range reported by Ainie and Hamirin (1994) who stated that the T.N. of toilet soap ranged from 39.2 to $43.2^{\circ} \mathrm{C}$.

\subsection{Effect of storage period at room temperature on some physical and chemical properties of the resultant toilet soaps}

During the hardening time of soap, the reaction between free alkali and free oil is continued since the soap feels warm to the touch [Head et al., 1995]. The soap samples were stored at room temperature for 6 months and the results are tabulated in Table VIII. From these data, it is event that the moisture contents of all soap samples were in gradually significant decreases at different ratios during the storage time and simultaneously, the contents of total fatty acids were in gradually significant increases at different ratios during the storage period. These data are closely related to the free moisture in the soap samples, which evaporated during the storage. These results are in agreement with that obtained by Girgis (1989).

Also, storage for 6 months caused significant improvements in some physical properties of all soap samples. The improvements in soap samples nos. 1,3,4 and 5 seem to be owing to significant increases in the contents of total fatty acids during the storage.

From the aforementioned results, it can be concluded that the best quality of the produced toilet soap samples, taking into account the physical and chemical properties as a guide, was in the increasing 


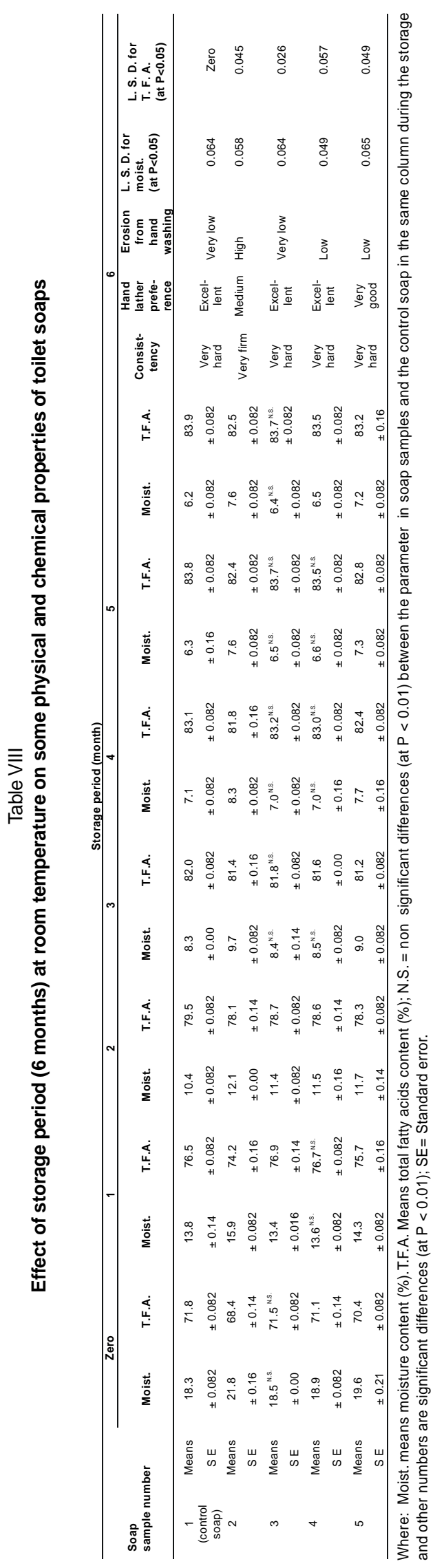


order: soap samples nos. 3, 4 and 5. It is worth noting that toilet soap no. 6 was not stored as a result of the fact that its consistency was not good from the start and therefore not suitable for use. Thus, it can be concluded that soap samples that contained P.B.D.P.O. up to $30 \%$ [instead of I.T. in toilet soap] are fit for use compared to the control soap (soap no. 1).

\section{CONCLUSIONS}

It could be concluded that discarded palm oil from chip factories can be used after its purification and bleaching up to $30 \%$ in place of inedible tallow in the manufacturing of toilet soap. Consequently, the present study aimed to reduce the quantity of imported inedible tallow and to reduce the production cost of toilet soap, as well as to lessen environmental pollution.

\section{REFERENCES}

Ainie, K. and Hamirin, K. (1994). Palm-based soap, in Selected reading on palm oil and its uses, p. 183-196. Palm Oil Research Institute of Malaysia (PORIM), Malaysia.

Ainie, K., Hamirin, K. and Peang-Kean, L. (1996). Chemical and physical characteristics of soap made from distilled fatty acids of palm oil and palm kernel oil. J. Am. Oil Chem. Soc., 73,105-108.

A.O.C.S. (1993 and 1997). Official and Tentative Methods for the American Oil Chemist's Society. 6 and $7^{\text {th }}$ ed. American Oil Chemist's Society, Champaign, U.S.A.

Chong, C. (1994). Chemical and physical properties of palm oil and palm kernel oil, in Selected reading on palm oil and its uses, p. 61-66. Palm Oil Research Institute of Malaysia (PORIM), Malaysia.

Clark, W. and Serbia, G. (1991). Safety aspects of frying fats and oils. Food Technology, March, 84-89.

Donald, B. and Halloran, K. (1991). Washing, refining, bleaching, deodorization and hydrogenation, in Soap technology for the 1990's, Chapter 3, p. 99. S. Luis, (Ed.) Am. Oil Chem. Soc., U.S.A.

Edmund, D. G. (1994). Fatty acid distribution of fats, oils, and soaps by high - performance liquid chromatography without derivatization. J. Am. Oil Chem. Soc. 71, $789-791$.

El-Sharkawy, A.A., Ibrahim, S.S. and Ismail, M.M. (1979). The effect of frying some foods on some properties of cottonseed oil. Agricultural Research Review, 57 (3) 67-72.

Firestone, D., Stier, R. and Blumenthal, M. (1990). Regulation of frying fats and oils. Food Technology, February, $9-14$

Ginn, M.E., Steinbauer, R.C., Liebman, D. and Eungermann, E. (1968). Effect of tallow-coconut fatty acid ratios on properties of bar soaps. J. Am. Oil Chem. Soc., 45, 666-669.

Girgis, A.Y. (1989). Studies on the manufacture of soap, p. 53. M. Sc. Thesis, Faculty of Agric., Zagazig Univ., Egypt.

Head, S., Swetman, A., Hammonds, T. and Harris, R. (1995). Oil seed products and further processing, in Small-scale vegetable oil extraction, p. 83. Natural Resource Institute, Kent, United Kingdom.

Hilda, B. (1993). Poucher's perfumes, cosmetics and soaps, Vol. 3, p. 395. Chapman and Hall, London.
Hui, Y.H. (1996). Soap, in Bailey's industrial oil and fat products, Vol. 5, p. 93. A Wiley Interscience Publication, John Wiley and Sons Inc., New York, U.S.A.

Iftikar, A. (1981). Use of palm stearin in soap, p. 1-9. Occasional paper no. 2. Palm Oil Research Institute of Malaysia (PORIM), Malaysia.

Izaki, Y., Yoshikawa, S. and Ochiyama, N. (1984). Effect of ingestion of thermally oxidized frying oil on peroxidative criteria in rats. Lipids, 19, 324-331.

Jaya, G., Ainie, K. and Ckeak, K. (2000). Quality bar soaps from palm - based soap noodles. Palm Oil Technical Bulletin, a Publication of the Malaysian Palm Oil Board (MPOB), 6 (6) $2-3$

Kaoru, T. (1998). Surface activity: Principles, phenomena and application, p. 21-22. Academic Press, San Diego.

Karimah, A., Aminah, A. and Mohd, K. (2001). Potential of palm blend in the formulation of mozzarella analogue. Palm Oil Development. Malaysia Palm Oil Board, 35, 1-7.

Leszkiewicz, B. and Kasperek, M. (1988). The effect of heat treatment on fatty acids of rapeseed oils. J. Am. Oil Chem. Soc., 65 (9) 1511-1514.

Ludy, J.E., Barford, R.A., Bard, S.F. and Magidman, D. (1968). A rapid and quantitative procedure for the preparation of methyl esters of butter oil and other fats. J. Am. Oil Chem. Soc., 45, 549-552.

Martin, G. (1951). The modern soap and detergent industry, Vol. 2, p. 5-11. The Tech. Press Ltd., London.

Ogoshi, T. and Miyawaki, Y. (1985). Soap and related products; palm and lauric oils. J. Am. Oil Chem. Soc., 62, 331-334.

Perkins, E. and Van Akkeren, L. (1965). Heated fats. IV. Changes in fats subjected to deep fat frying processes. J. Am. Oil Chem. Soc., 42, 782-785.

Salmiah, A. (1994). Palm based oleochemicals and their uses, in Selected reading on palm oil and its uses, $\mathrm{p}$. 162. Palm Oil research Institute of Malaysia (PORIM), Malaysia.

SAS (1996). Statistical Analysis System, SAS User's Guide: Statistical. SAS Institute Inc. N.C. Cary (Ed).

Shyam, G. (1991). Chemistry, chemical and physical properties and raw materials, in Soap technology for the 1990's, Chapter 2, p. 70-88. S. Luis (Ed.), Am. Oil Chem. Soc., U.S.A.

Sonntay, N.O. (1981). Current future fat-based raw materials for soap manufacture. J. Am. Oil Chem. Soc., 58 (2) $155 \mathrm{~A}-161 \mathrm{~A}$.

The Egyptian Industry Ministry (2002). The annual report of the Holding Company for Food Industrials, Cairo, Egypt.

The Egyptian Standard Specifications (1992). Egyptian Standard (1044/1992) for Toilet Soap. Egyptian Organization for Standardization and Quality Control, Ministry of Industry, Cairo, Egypt.

Tyagi, V.K. and Vasishtha, A.K. (1996). Changes in the characteristics and composition of oils during deep-fat frying. J. Am. Oil Chem. Soc., 73 (4), 499-506.

Wishner, L. and Keeney, M. (1965). Comparative study of monocarbonyl compounds formed during deep frying in different fats. J. Am. Oil Chem., Soc., 42, 776-779.

Woollatt, E. (1985). The manufacture of soaps, other detergents and glycerine, p. 42-46. Ellis Horwood Limited, Chester, England.

Zygadlo, J.A., Morero, R.E., Abburra, R.E. and Guzman, C.A. (1994). Fatty acid composition in seed oils of some onagraceae. J. Am. Oil Chem. Soc., 71, 915-916.

Recibido: Mayo 2003 Aceptado: Enero 2004 